УДК 657.1

JEL classification: M41

Скоробогатова Н. С. канд. економ. наук, дочент ORCID ID: 0000-0002-2741-7629

Кухарук А. Д. канд. економ. наук, доцент ORCID ID: 0000-0002-2792-4137

Національний технічний університет Украӥни «Київський політехнічний інститут імені Ігоря Сікорського»

\title{
АДАПТАЦІЯ УКРАЇНСЬКОГО ЗАКОНОДАВСТВА У СФЕРІ БУХГАЛТЕРСЬКОГО ОБЛІКУ ТА ЗВІТНОСТІ ДО ВИМОГ ЕС
}

\section{ADAPTATION OF UKRAINIAN ACCOUNTABILITY AND ACCOUNTING POLICIES TO THE EU REQUIREMENT}

Статтю присвячено аналізу останніх змін украӥнського законодавства у сфері бухгалтерського обліку та фінансової звітності з метою імплементації норм директив $С С$. Визначено розбіжності у класифікаиї підприємств за розмірами відповідно до норм закону Украйни «Про бухгалтерський облік та фінансову звітність» та Господарського кодексу України. Окреслено умови віднесення вітчизняних підприємств до тих, щуо становлять суспільний інтерес. Визначено позитивні зміни у методології бухгалтерського обліку підприємств в результаті ї̈ адаптації до вимог СС: відкритість інформації, таксономія звітності на держсавному рівні, прозорість діяльності, спрощення порядку документального оформлення операчій, запровадження нефінансової звітності. Проаналізовано структуру та вимоги до складання звітності зі сталого розвитку підприємств за міжнародними стандартами. Досліджено тенденції поширення практики складання звітності на засадах корпоративної соціальної відповідальності в Україні та світі. Виявлено, щэо останні роки спостерігається поширення практики складання нефінансової звітності, як в Украӥні, так $i$ у світовому масштабі. Виділено недоліки існуючих підходів до запровадження нефінансової звітності вітчизняними підприємствами (недостатній рівень обізнаності фахівців підприємств щзодо методології корпоративної соиіальної відповідальності; відсутність уніфікованого складу фінансових та нефінансових показників нефінансової звітності; завищення иілей та напрямів розвитку підприємств задля підвищення рівня привабливості підприсмства тощз), подолання яких сприятиме підвищенню ефективності бізнесу та його привабливості серед суспільства та контрагентів. Визначено переваги імплементації норм європейського законодавства у сфері бухгалтерського обліку для вітчизняних підприємств: надання більш детальної та доступної для європейських партнерів інформачії сприятиме підвищенню рівня інвестииійної привабливості; підвищення ефективності механізму організації облікових прочедур, а також запровадження прозорих інструментів управління та моніторингу витрат і результатів діяльності підвищить рівень довіри потениійних інвесторів, партнерів, суспільства.

Ключові слова: бухгалтерський облік, фінансова звітність, сталий розвиток, нефінансова звітність, корпоративна соціальна відповідальність, гармонізація обліку, види підприємств, звіт з управління.

The article is devoted to the analysis of recent changes in the Ukrainian legislation in the field of accounting and financial reporting in order to implement the norms of the EU directives. The 
differences in the classification of enterprises by size are determined in accordance with the norms of the Law of Ukraine "On Accounting and Financial Reporting" and the Commercial Code of Ukraine. The conditions for assigning domestic enterprises to those of public interest are outlined. The positive changes in the accounting methodology of enterprises as a result of its adaptation to EU requirements were determined: openness of information, taxonomy of reporting at the state level, transparency of activity, simplification of the procedure for documentary registration of operations, introduction of non-financial reporting. The structure and requirements for compilation of reports on sustainable development of enterprises according to international standards are analyzed. The tendencies of the practice of reporting on the principles of corporate social responsibility in Ukraine and the world are investigated. The spread of the practice of compiling non-financial reporting, both in Ukraine and globally, was revealed. The shortcomings of existing approaches to the introduction of non-financial reporting by domestic enterprises are highlighted (lack of awareness of the specialists of enterprises on the methodology of corporate social responsibility, the lack of unified financial and non-financial indicators of non-financial reporting, overestimation of goals and directions of enterprise development in order to increase the level of attractiveness of the enterprise, etc.), the overcoming of which will help to increase the efficiency of business and its attractiveness among society and counterparties. The advantages of implementation of the norms of the European legislation in the field of accounting for domestic enterprises are determined: the provision of more detailed and accessible information for European partners will increase the level of investment attractiveness; increasing the efficiency of the mechanism of organization of accounting procedures, as well as the introduction of transparent tools for managing and monitoring costs and performance will increase the confidence of potential investors, partners, society.

Keywords: accounting, financial reporting, sustainable development, non-financial reporting, corporate social responsibility, accounting harmonization, types of enterprises, management report.

Вступ. Розширення рамок міжнародного співробітництва сприяє розвиткові зовнішньоекономічних операцій, створенню спільних підприємств, транснаціональних корпорацій тощо. В умовах глобалізації світової економіки необхідною умовою є уніфікація вимог та методичних підходів до ведення обліку господарської діяльності та складання фінансової звітності підприємств різних країн, що дозволить інвесторам та контрагентам порівнювати інформацію, визначати реальне становище підприємств партнерів, оцінювати привабливість об'єкту інвестування. Останні десятиліття в Україні відбувається процес гармонізації обліку з міжнародними стандартами та директивами СС. Зокрема, національні положення бухгалтерського обліку розроблені на основі міжнародних стандартів бухгалтерського обліку та фінансової звітності.

Проблемам реформування бухгалтерського обліку присвячені роботи багатьох вітчизняних науковців, серед яких слід відзначити Ф. Бутинця [17], С. Голова [18], В. Єфіменка [19], В. Пархоменка [20], С. Свірко [21], Ю. Кузьмінського [23], М. Кужельного [22], Л. Кіндрацьку, А. Фаріон та інших. Проте і на сьогодні залишаються певні неузгоджені питання, що заважають ефективній співпраці вітчизняних та іноземних партнерів.

Постановка завдання. Метою дослідження $\epsilon$ аналіз трансформації законодавчих норм щодо організації бухгалтерського обліку та складання звітності в Україні 3 врахуванням вимог європейського законодавства та 
підвищення рівня інвестиційної привабливості країни. Для досягнення поставленої мети було визначено такі завдання:

- проаналізувати зміни законодавства України у сфері бухгалтерського обліку з врахуванням директив ЄС та визначити їх вплив на діяльність підприємств;

- дослідити методичні підходи до формування нефінансових звітів у вітчизняній та світовій практиці;

- виокремити проблеми й недоліки запровадження концепції корпоративної соціальної відповідальності та відображення у звітності вітчизняних підприємств;

- визначити переваги імплементації директив СС щодо обліку та фінансової звітності для українських підприємств.

Методологія. Теоретико-методологічну основу дослідження становлять наукові праці провідних вітчизняних учених у сфері реформування бухгалтерського обліку, нормативно-правова база щодо обліку та фінансової звітності, нефінансова звітність вітчизняних підприємств. Вирішення наукових завдань здійснювалось з використанням наступних методів дослідження: аналізу та синтезу (для дослідження змін законодавства України у сфері бухгалтерського обліку та фінансової звітності); методи порівняння та узагальнення (для аналізу вітчизняної практики та зарубіжного досвіду формування нефінансових звітів); системний і комплексний підходи (для виділення проблем та перспектив подальшого розвитку підприємств в результаті імплементації директив ЄС у сфері бухгалтерського обліку та звітності).

Результати дослідження. Методологічною основою забезпечення зрозумілості та порівнянності фінансової звітності для інвесторів та контрагентів різних країн виступають Міжнародні стандарти фінансової звітності (МСФЗ). Вони містять загальні принципи та підходи до відображення господарської діяльності в бухгалтерському обліку та фінансовій звітності. МСФЗ є основою для розробки національних стандартів (положень) бухгалтерського обліку багатьох країн, у тому числі й України. Гармонізація бухгалтерського обліку в ЄС здійснюється також за допомогою відповідних директив, які $\epsilon$ обов'язковими до виконання всіма країнами-членами. Адаптація законодавства України у сфері обліку та звітності до вимог МСФЗ та законодавства ЄС здійснюється шляхом затвердження національних (положень) стандартів бухгалтерського обліку та фінансової звітності, закону України «Про бухгалтерський облік та фінансову звітність», внесення до них відповідних змін тощо. Останні зміни у жовтні 2017 року, коли було внесено зміни до Закону України «Про бухгалтерський облік та фінансову звітність». Відповідно до прийнятого Закону України «Про внесення змін до Закону України «Про бухгалтерський облік та фінансову звітність в Україні» щодо удосконалення деяких положень» від 05.10.2017 р. № 2164-VIII [1], має відбутися перехід значної кількості вітчизняних підприємств до застосування Міжнародних стандартів фінансової звітності (МСФЗ), починаючи з 1 січня 2018 року. При цьому виникає низка проблем як законодавчого плану, так і ряд практичних аспектів реалізації передбачених законодавством змін. По-перше, 
слід відзначити деякі неузгодженості на законодавчому рівні щодо визначення видів підприємств, а відповідно, і обов'язків щодо ведення обліку, подання звітності та оподаткування кожного 3 них. Так статтею 55 Господарського кодексу України [26] (ГКУ) передбачено поділ суб'єктів господарювання на види: великі, середні, малі та мікро (табл. 1):

Таблиця 1- Класифікація суб’єктів господарювання (відповідно до ГКУ)

\begin{tabular}{|c|c|c|c|c|c|c|}
\hline \multirow{2}{*}{$\begin{array}{c}\text { Критерій } \\
\text { у розрахунку } \\
\text { за звітний } \\
\text { період } \\
\text { (календарний } \\
\text { рік) }\end{array}$} & \multicolumn{2}{|c|}{$\begin{array}{c}\text { Суб'єкти } \\
\text { мікропідприєм- } \\
\text { ництва }\end{array}$} & \multicolumn{2}{|c|}{$\begin{array}{l}\text { Суб'єкти малого } \\
\text { підприємництва }\end{array}$} & \multirow{2}{*}{$\begin{array}{c}\text { Суб'єкти } \\
\text { середнього } \\
\begin{array}{c}\text { підприємниц- } \\
\text { тва }\end{array} \\
\begin{array}{c}\text { Юридичні } \\
\text { особи }\end{array}\end{array}$} & \multirow{2}{*}{$\begin{array}{c}\begin{array}{c}\text { Суб'єкти } \\
\text { великого } \\
\text { підприємниц- } \\
\text { тва }\end{array} \\
\begin{array}{c}\text { Юридичні } \\
\text { особи }\end{array}\end{array}$} \\
\hline & $\begin{array}{c}\text { Фізичні } \\
\text { особи- } \\
\text { підприємці }\end{array}$ & $\begin{array}{r}\text { Юридич- } \\
\text { ні особи }\end{array}$ & $\begin{array}{c}\text { Фізичні } \\
\text { особи- } \\
\text { підприємці }\end{array}$ & $\begin{array}{l}\text { Юридич- } \\
\text { ні особи }\end{array}$ & & \\
\hline $\begin{array}{l}\text { Середня } \\
\text { кількість } \\
\text { працівників }\end{array}$ & \multicolumn{2}{|c|}{ не перевищує 10 осіб } & \multicolumn{2}{|c|}{ не перевищує 50 осіб } & $50-250$ осіб & $\begin{array}{l}\text { перевищує } \\
250 \text { осіб }\end{array}$ \\
\hline Річний дохід & \multicolumn{2}{|c|}{$\begin{array}{c}\text { не перевищує суму, } \\
\text { еквівалентну } \\
2 \text { млн євро }\end{array}$} & \multicolumn{2}{|c|}{$\begin{array}{c}\text { не перевищує суму, } \\
\text { еквівалентну } \\
\text { млн євро }\end{array}$} & $\begin{array}{c}\text { від } 10 \text { до } 50 \\
\text { млн євро }\end{array}$ & $\begin{array}{c}\text { не перевищує } \\
\text { суму, } \\
\text { еквівалентну } \\
50 \text { млн євро }\end{array}$ \\
\hline
\end{tabular}

(складено авторами за джерелом [26])

Такого ж розподілу суб’єктів підприємництва дотримується і Державна фіскальна служба України для визначення груп платників податків та умов подання податкової звітності, сплати податків і зборів [2]. Водночас, відповідно до прийнятих змін до Закону України «Про бухгалтерський облік та фінансову звітність в Україні» [1], підприємства поділяються на великі, середні, малі та мікропідприємства за іншими кількісними ознаками, що відповідають європейському законодавству [5] (табл. 2):

Таблиия 2 - Класифікація суб'єктів господарювання (відповідно до Закону України «Про бухгалтерський облік та фінансову звітність в Україні»)

\begin{tabular}{|c|c|c|c|c|}
\hline \multirow{2}{*}{$\begin{array}{c}\text { Показники на дату складання річної } \\
\text { фінансової звітності за рік, що передує } \\
\text { звітному (відповідність щонайменше за } \\
\text { двома } 3 \text { критеріїв) }\end{array}$} & $\begin{array}{l}\text { Мікро- } \\
\text { підприєм- } \\
\text { ства }\end{array}$ & $\begin{array}{c}\text { Малі } \\
\text { підприєм- } \\
\text { ства }\end{array}$ & $\begin{array}{c}\text { Середнi } \\
\text { підприєм- } \\
\text { ства }\end{array}$ & $\begin{array}{c}\text { Великі } \\
\text { підприєм- } \\
\text { ства }\end{array}$ \\
\hline & \multicolumn{4}{|c|}{ Юридичні особи } \\
\hline Середня кількість працівників & $\begin{array}{c}\text { не } \\
\text { перевищує } \\
10 \text { осіб }\end{array}$ & $\begin{array}{c}\text { не } \\
\text { перевищує } \\
50 \text { осіб }\end{array}$ & $\begin{array}{c}\text { не } \\
\text { перевищує } \\
250 \text { осіб }\end{array}$ & $\begin{array}{l}\text { перевищує } \\
250 \text { осіб }\end{array}$ \\
\hline $\begin{array}{l}\text { Чистий дохід від реалізації продукції } \\
\text { (товарів, робіт, послуг) }\end{array}$ & $\begin{array}{c}\text { не } \\
\text { перевищує } \\
700 \text { тис євро }\end{array}$ & $\begin{array}{c}\text { не } \\
\text { перевищує } \\
8 \text { млн євро }\end{array}$ & $\begin{array}{l}\text { до } 40 \text { млн } \\
\text { євро }\end{array}$ & $\begin{array}{c}\text { понад } \\
40 \text { млн євро }\end{array}$ \\
\hline Балансова вартість активів & $\begin{array}{l}\text { до } 350 \text { тис. } \\
\text { євро }\end{array}$ & $\begin{array}{c}\text { до } 4 \text { млн } \\
\text { євро }\end{array}$ & $\begin{array}{l}\text { до } 20 \text { млн } \\
\text { євро }\end{array}$ & $\begin{array}{c}\text { понад } \\
20 \text { млн євро }\end{array}$ \\
\hline
\end{tabular}

(складено авторами за джерелом [1]) 
Таким чином, до узгодження критеріїв віднесення суб'єктів господарювання до великих, середніх, малих та мікропідприємств, вони будуть віднесені до різних груп відповідно до вимог бухгалтерського та податкового законодавства. Що стосується фізичних осіб-підприємців, то вони не мають вести бухгалтерських облік, на відміну від юридичних осіб, які повинні вести як бухгалтерський, так і податковий облік.

Окрім того, законом [1] вводиться визначення підприємств, що становлять суспільний інтерес, - це підприємства - «емітенти цінних паперів, цінні папери яких допущені до біржових торгів, банки, страховики, недержавні пенсійні фонди, інші фінансові установи (крім інших фінансових установ та недержавних пенсійних фондів, що належать до мікропідприємств та малих підприємств) та підприємства, які відповідно до цього закону належать до великих підприємств» [1]. Такі підприємства зобов'язані утворити бухгалтерську службу на чолі 3 головним бухгалтером, загальною кількістю штату не менше двох осіб. Окрім того, висуваються професійно-кваліфікаційні вимоги до головного бухгалтера суспільного підприємства, а саме: повна вища освіта; стаж роботи у сфері фінансів, бухгалтерського обліку та оподаткування не менше трьох років; відсутність непогашеної або незнятої судимості за вчинення злочину проти власності та у сфері господарської діяльності. Такі підприємства зобов'язані публічно розкривати свою фінансову звітність, яку повинні складати за вимогами МСФЗ. За даними Державної служби статистики України, станом на кінець 2016 року в Україні було зареєстровано 306369 підприємств, серед яких $95 \%$ становлять малі [3]. Тобто, потенційно законодавчі зміни щодо порядку організації бухгалтерського обліку та складання фінансової звітності мають торкнутися невеликої кількості підприємств. Проте необхідно прийняти до уваги, що критерії віднесення підприємств до груп великих, середніх та малих різняться за методикою Державної служби статистики України та за нормами закону про бухгалтерський облік. Також, слід врахувати той факт, що відповідно до закону [1], враховуються не лише розміри, але й види діяльності підприємств. Тому можна передбачати, що питання врахування змін до порядку ведення бухгалтерського обліку та складання фінансової звітності буде стосуватися значної кількості українських юридичних осіб.

Також позитивною зміною є прописана у законі [1] норма про відкритість та загальнодоступність до фінансової звітності підприємств, яка й до того була передбачена положеннями бухгалтерського обліку, але фактично не завжди дотримувалася менеджментом приватних підприємств на практиці. Тобто, підприємства зобов'язані надавати копії фінансової звітності за вимогою трудового колективу, за запитами фізичних та юридичних осіб, оскільки інформація в ній не є комерційною таємницею [4]. Для підприємств, що становлять суспільний інтерес (крім великих підприємств, які не $є$ емітентами цінних паперів), публічних акціонерних товариств, суб'єктів природних монополій та підприємств, які здійснюють діяльність з видобутку корисних копалин загальнодержавного значення, обов'язковим $\epsilon$ оприлюднення річної 
фінансової звітності, підтвердженої аудиторським висновком, не пізніше ніж до 30 квітня року, що настає за звітним періодом, на своїй веб-сторінці. Великі підприємства, які не є емітентами цінних паперів, середні підприємства та інші фінансові установи, що належать до мікро- та малих підприємств, зобов'язані це робити до 1 червня [1].

3 метою уніфікації статей фінансової звітності законом [1] передбачається таксономія звітності на державному рівні, тобто чітко визначений склад статей $і$ показників фінансової звітності та її елементів, які підлягають розкриттю, що надає можливість здійснювати порівняльний аналіз конкурентів та аналіз динаміки розвитку власного підприємства.

Водночас позитивною зміною у порядку ведення бухгалтерського обліку можна вважати фактичне визнання принципу превалювання сутності над формою, а саме: неістотні недоліки у первинних документах відтепер не $\epsilon$ підставою для невизнання господарської операції. Тобто за умови, що такі недоліки не перешкоджають можливості ідентифікувати особу, яка брала участь у здійсненні господарської операції, та містять відомості про дату складання документа, назву підприємства, від імені якого складено документ, зміст та обсяг господарської операції первинні документи вважаються підтвердженням господарської операції.

Нововведенням аналізованого закону є нова форма звітності, яку мають складати великі та середні підприємства, - звіт про управління. Це документ, що містить фінансову та нефінансову інформацію, яка характеризує стан i перспективи розвитку підприємства та розкриває основні ризики i невизначеності його діяльності [1]. Слід відзначити, що починаючи з 2012 року, вітчизняні фінансові установи (утворені у формі акціонерних товариств) щорічно складали звіт про корпоративне управління з інформацією про:

- мету провадження діяльності;

- дотримання / недотримання принципів чи кодексу корпоративного управління, причин відхилення;

- власників істотної участі, зміну їх складу за рік;

- склад наглядової ради, виконавчого органу та їх зміни за рік;

- факти порушення членами наглядової ради та виконавчого органу внутрішніх правил, що призвели до шкоди установі або споживачам;

- фактори ризику, що впливали на діяльність установи, та наявність системи управління ризиками (ії характеристики);

- результати роботи системи внутрішнього аудиту (контролю) тощо [6].

Даний звіт, відповідно до [5], має бути елементом звіту про управління. На жаль, вітчизняне законодавство на даний час не містить жодних пояснень щодо елементів та умов складання останнього. Проте Директива ЄС № 2013/34/СС [5], відповідно до норм якої були внесені зміни до закону про бухгалтерський облік [1], містить стислу інформацію щодо складових звіту про управління. Даній звіт має надавати інформацію, необхідну для інвесторів, учасників та інших осіб поряд 3 даними фінансової звітності підприємств. Водночас, законодавство СС 
щодо фінансової звітності передбачає досягнення балансу між інтересами користувачів фінансової звітності та надмірним обтяженням підприємств вимогами до звітності. Звіт про управління має надавати справедливий огляд розвитку підприємства та аналіз сучасного стану, включаючи не лише фінансові аспекти його господарської діяльності, але й екологічні та соціальні аспекти.

Слід зазначити, що і до дати внесення змін до закону про бухгалтерський облік [1] деякі українські підприємства складали та оприлюднювали на власних сайтах нефінансові звіти [12], які базуються на принципах корпоративної соціальної відповідальності [10] для досягнення сталого розвитку суспільства. Надаючи звітність щодо сталого розвитку, підприємство підтверджує, що дотримується у своїй діяльності принципів корпоративної соціальної відповідальності, до яких у найбільш широкому розумінні відносять:

- підзвітність - організація має звітувати щодо впливу від своєї діяльності на суспільство і довкілля;

- прозорість - суб'єктам господарської діяльності потрібно бути прозорими в їх рішеннях і діяльності, які впливають на інших;

- гуманність - визнання важливості і загальності прав людини, зазначених у Всесвітній Декларації з прав людини;

- страх як категорія, що обмежує ті сфери, на які за жодних умов не повинен поширюватися вплив людини (страх за майбутнє людства, породжений благоговінням перед життям);

- поміркованість у прийнятті тих чи інших рішень (мета поміркованості збереження життя, і лише майбутнє покоління здатне повноцінно оцінити наслідки теперішньої діяльності);

- патріотизм як розуміння цінності та унікальності Батьківщини;

- відчуття обов'язку як моральні зобов'язання людини, котрі вона виконує з почуттям совісті;

- моральність як особлива сфера суспільної свідомості та вид суспільних відносин, мета яких сформувати способи нормативного регулювання поведінки i дій людей у суспільстві за допомогою норм, принципів і категорій моралі;

- духовність як процес гармонійного розвитку духовних задатків людини;

- професійна компетентність як знання, досвід, здобування освіти 3 відповідної галузі діяльності;

- творча спрямованість як схильність до творчої ініціативи;

- працелюбність як риса характеру, котра полягає у позитивному ставленні особистості до процесу трудової діяльності, що виражається через активність, ініціативність, добросовісність, дисциплінованість тощо $[24$, с. 1617].

Методологічні засади формування нефінансової звітності визначають відповідні стандарти, найпоширенішим серед яких є стандарт GRI (Global Reporting Initiative). Розробкою стандартів у сфері сталого розвитку займається Глобальна Рада GSSB, яка у 2013 р. випустила вже четверту версію Керівництва 
GRI G4 [13], що враховує зауваження до попередніх версій та відгуки компанійкористувачів. 3 часом поширилася популярність практики складання нефінансових звітів. На даний час у нефінансову звітність за стандартами GRI складають більше 4000 компаній, що є представниками як великого, так і малого бізнесу (рис. 1):

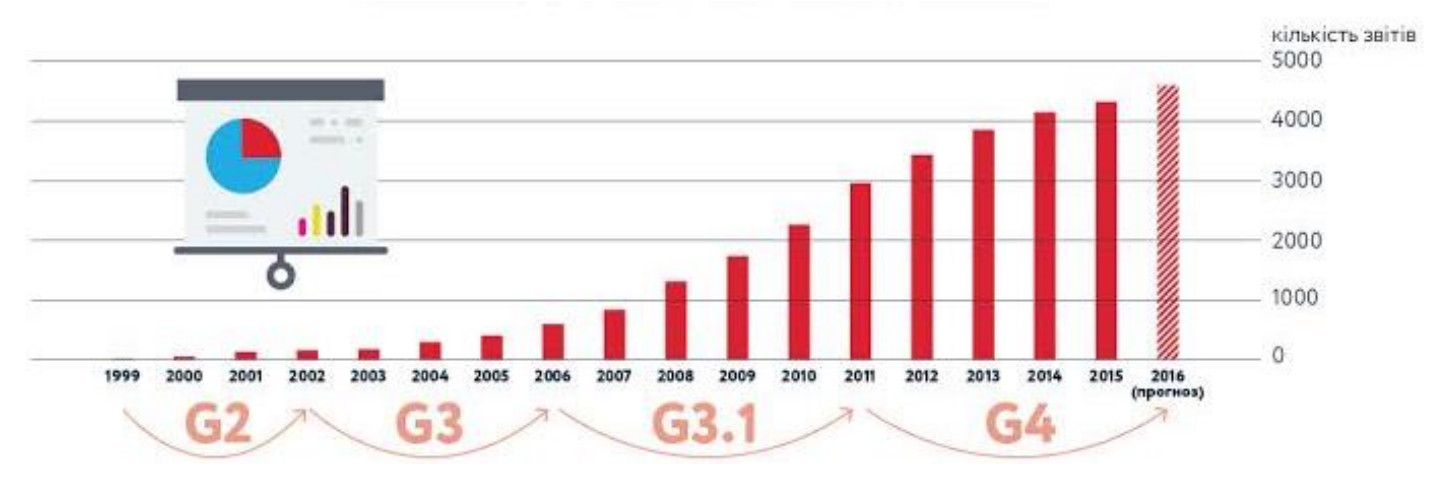

Рисунок 1 - Нефінансова звітність за GRI [25]

В Україні протягом останніх десяти років також поширюється практика складання нефінансової звітності, проте у значно менших масштабах (рис. 2):

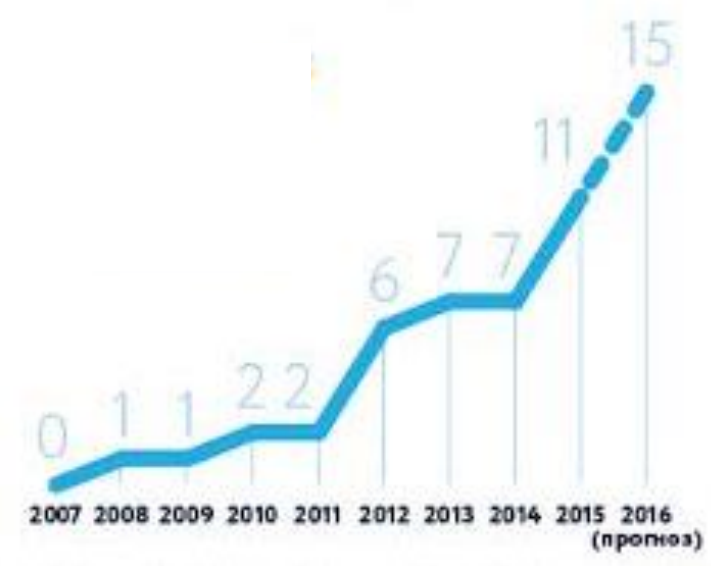

Рисунок 2 - Кількість українських компаній, що підготували нефінансову звітність за GRI (од.) [25]

Проведений аналіз показав, що інформація, яка міститься на офіційних сайтах більшої частини вітчизняних компаній у розділі корпоративної соціальної відповідальності, фактично $\epsilon$ напрямками розвитку соціальної відповідальності, а не звітами. Закріплення на законодавчому рівні обов'язкового застосування нефінансових звітів (у літературі є різні визначення: нефінансові звіти $[11,14]$, звіти про сталий розвиток [7, 13], звіти про корпоративну соціальну відповідальність $[10,14])$ - це суттєвий крок до європейських стандартів ведення бізнесу прозоро та відповідально: сигнал іноземному інвесторові про те, що компанія має довгостроковий план розвитку, піклується про свою репутацію, і відповідно, заслуговує на довіру [7]. 
1 січня 2016 р. вступили в силу17 глобальних цілей сталого розвитку, які були затверджені на саміті ООН з питань сталого розвитку у вересні 2015 р. та імплементовані Україною [9] (рис. 3).

1. Подолання бідності в усіх іï формах і всюди

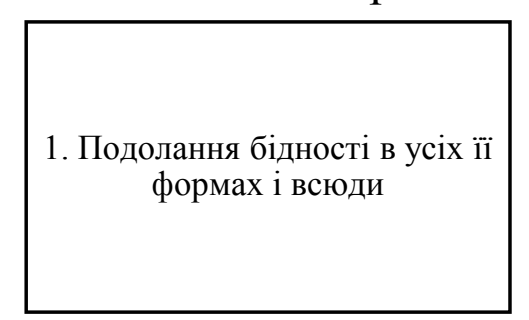

4. Забезпечення всеохоплюючої і справедливої якісної освіти та заохочення можливості навчання впродовж усього життя для Bcix

7. Забезпечення доступу до недорогих, надійних, стійких і сучасних джерел енергії для Bcix

10. Скорочення нерівності всередині країн і між ними

13. Вживання невідкладних заходів щодо боротьби зі зміною клімату та іiі наслідками
2. Подолання голоду, досягнення продовольчої

безпеки, поліпшення

харчування і сприяння сталому розвитку сільського господарства

5. Забезпечення гендерної рівності, розширення прав $\mathrm{i}$ можливостей усіх жінок та дівчат

8. Сприяння поступальному, всеохоплюючому та сталому економічному зростанню, повній і продуктивній зайнятості та гідній праці для вcix

11. Звідкритості, безпеки, життєстійкості й екологічної стійкості міст і населених пунктів

14. Збереження та раціональне використання океанів морів і морських ресурсів в інтересах сталого розвитку
3. Забезпечення здорового способу життя та сприяння благополуччю для всіх у будьякому віці

6. Забезпечення наявності та раціонального використання водних ресурсів і санітарії для Bcix

9. Створення стійкої інфраструктури, сприяння всеохоплюючій і сталій індустріалізації та інноваціям

12. Забезпечення переходу до раціональних моделей споживання і виробництва

15. Захист і відновлення екосистем суші та сприяння їх раціональному використанню, раціональне лісокористування,

боротьба $з$ опустелюванням, припинення і повернення назад (розвертання) процесу деградації земель та зупинка процесу втрати біорізноманіття
16. Сприяння побудові миролюбного й відкритого суспільства в інтересах сталого розвитку, забезпечення доступу до правосуддя для всіх і створення ефективних, підзвітних та заснованих на широкій участі інституцій на всіх рівнях
17. Зміцнення засобів здійснення й активізація роботи в рамках Глобального партнерства в інтересах сталого розвитку

\section{Рисунок 3 - Глобальні цілі сталого розвитку (складено авторами за джерелом [8])}

Таким чином, нефінансові звіти - це звіти компаній (підприємств), які містять не лише економічні, а й соціальні та екологічні показники. Дані звіти $\epsilon$ 
публічними, вони виступають інструментом інформування власників, співробітників, партнерів, клієнтів, суспільства про темпи розвитку компанії, реалізацію стратегії сталого розвитку у розрізі економічної, соціальної та екологічної складової.

Аналіз нефінансових звітів вітчизняних підприємств свідчить про наявність певних проблемних моментів, а саме:

- недостатній рівень обізнаності провідних фахівців підприємств щодо сутності корпоративної соціальної відповідальності, методики складання нефінансових звітів, вибору та обчислення відповідних показників, що призводить до формального підходу у розробці, висвітленні стратегії сталого розвитку підприємства та відповідних звітів щодо її виконання;

- відсутність єдиного переліку фінансових та нефінансових показників, які повинні містити дані звіти, призводить до відсутності порівнянності результатів різних підприємств, навіть належних до однієї галузі діяльності. Керівництво G4 [14] містить лише перелік аспектів та індикаторів, що відображають напрямки, за якими повинна відображатися інформація;

- на практиці метою складання нефінансових звітів є представлення підприємств у більш привабливому вигляді для інвесторів, суспільства та держави із зазначенням завищених цілей, які нерідко є фактично нездійсненими.

Водночас, до переваг імплементації європейського законодавства у сфері бухгалтерського обліку та звітності можна віднести наступні:

- фінансова звітність, складена із застосуванням МСФЗ, надає власникам підприємств детальнішу інформацію, ніж 3 використанням національних стандартів бухгалтерського обліку;

- поява можливості більш ефективної організації ведення бізнесу, оскільки з'являється можливість вести облік 3 врахуванням власних організаційно-економічних механізмів;

- підвищується рівень інвестиційної привабливості підприємства через можливість виходу на нові, закордонні ринки капіталу, оскільки іноземним інвесторам зрозуміла звітність, складена за МСФЗ, а також підвищується рівень довіри до підприємства, що позитивно позначається на його конкурентоспроможності;

- запровадження практики складання нефінансової звітності робить прозорими цілі, напрями розвитку підприємства та результати їх досягнення; підвищує рівень довіри інвесторів, суспільства та сприяє формуванню позитивного іміджу підприємства.

Висновки. В результаті проведеного дослідження встановлено, що протягом останніх двадцяти років в Україні здійснюється покроковий процес гармонізації бухгалтерського обліку та фінансової звітності відповідно до вимог МСФЗ та директив ЄС, що сприяє однозначному розумінню фінансової звітності та зростанню рівня довіри до показників, зазначених у ній. Новизною проведеного дослідження $є$ запропоновані напрями ідентифікації потенційних переваг від впровадження вимог європейського законодавства у сфері 
організації обліку та складання звітності у практику вітчизняних підприємств, а саме: підвищення ефективності механізму управління підприємством, розширення бази потенційних контрагентів та збільшення обсягів залучення інвестицій через прозорість складеної звітності, формування позитивного іміджу за рахунок реалізації концепції корпоративної відповідальності та сталого розвитку підприємств, ідентифікації та оцінки ризиків їх діяльності.

Практичне значення отриманих результатів полягає у систематизації напрямів та елементів, обов'язкових до розкриття у звіті про управління, відповідно до вимог європейського законодавства та світової практики.

Перспективним напрямом подальших досліджень $є$ розвиток наукових положень щодо формування бази індикаторів сталого розвитку підприємств 3 врахуванням економічної, соціальної та екологічної складових.

\section{Література:}

1. Закон України «Про внесення змін до Закону України «Про бухгалтерський облік та фінансову звітність в Україні» щодо удосконалення деяких положень» від 05.10.2017 р. № 2164-VIII. URL: http://zakon3.rada.gov.ua/laws/show/2164-19.

2. Про подання податкової консультації : лист Державної фіскальної служби України від 08.11.2016 p. № 24033/6/99-99-14-03-03-15. URL: https://docs.dtkt.ua/doc/1041.82203.0

3. Офіційний сайт Державної служб статистики України. URL: http://www.ukrstat.gov.ua/

4. Для бізнесу в Україні вводяться нові вимоги по бухгалтерії. URL: http://expres.ua/news/2017/10/09/266096-biznesu-ukrayini-vvodyatsya-novi-vymogy-pobuhgalteriyi.

5. Directive 2013/34/EU of the European Parliament and of the Council of 26 June 2013 on the annual financial statements, consolidated financial statements and related reports of certain types of undertakings, amending Directive 2006/43/EC of the European Parliament and of the Council and repealing Council Directives 78/660/EEC and 83/349/EEC. URL: http://eurlex.europa.eu/LexUriServ/LexUriServ.do?uri=OJ:L:2013:182: 0019:0076:EN:PDF

6. Про фінансові послуги та державне регулювання ринків фінансових послуг : Закон України від 12.07.2001 p. № 2664-III (редакція від 01.01 .2017 p.) URL: http://zakon3.rada.gov.ua/laws/show/2664-14/

7. Стандарти GRI: звітність у зрозумілому для інвесторів вигляді URL: http://ifrs.ligazakon.ua/ua/magazine_article/FZ001041

8. SDG COMPASS: Посібник для досягнення Цілей Сталого Розвитку в сфері бізнесу // Глобальна Ініціатива зі Звітності, Глобальний договір ООН, Всесвітня рада підприємців зі сталого розвитк. URL: https://sdgcompass.org/wpcontent/uploads/2016/09/SDG_Compass_Guide_Ukranian.pdf

9. Sustainable Development Goals: Ukraine (National baseline report). Ministry of economic development and trade of Ukraine. 2017. 168 p. [Електронний ресурс]. - Режим доступу: https://drive.google.com/drive/u/0/folders/0B9O3ySgVVRL5MTJHMFBqQUQtNkk

10.Принципи Корпоративної соціальної відповідальності // Sustainable business. URL: http://csrjournal.com/1446-principy-korporativnojj-socialnojj-otvetstvennosti.html

11. Семь вопросов о нефинансовой отчетности, на которые руководители компаний должны иметь ответ // Ernst \& Young. URL: http://www.ey.com/Publication/vwLUAssets/Seven-thingsCEOs-boards-should-ask-about-reporting-RU/\$FILE/Seven-things-CEOs-boards-should-askabout-reporting-RU.pdf

12. Центр Розвитку корпоративної соціальної відповідальності : офіційний сайт. URL: http://csr-ukraine.org/member/ 
13. G4: Руководство по отчетности в области устойчивого развития / Stichting Global Reporting Initiative. URL: https://www.globalreporting.org/resourcelibrary/Russian-G4-Part-One.pdf

14. Нефінансовий звіт ДП «НАЕК «Енергоатом»» за 2016 рік : офіційний сайт ДП «НАЕК «Енергоатом»»». URL: http://www.energoatom.kiev.ua/ua/actvts/sustainabledevelopment /non_financial_reporting/53144-energoatompershim_sered_derjavnih_pdprimstvprezentuvav rchniyi_nefnansoviyi_zvt/.

15. Царук В. Ю. Фінансова звітність підприємств в сучасних умовах господарювання: проблемні аспекти і перспективи розвитку // Подільський вісник: сільське господарство, техніка, економіка. Економічні науки. 2017. Випуск 26. С. 236 - 243.

16. Рєзнікова В.В., Орлова О. С. Перспективи гармонізації бухгалтерського обліку та фінансової звітності в Україні // Адміністративне право і процес. 2015. № 1 (11). С. 296 331.

17.Бутинець Ф. Ф. Реформування чи знищення обліку: кричу й благаю, а мене не чують // Вісник ЖДТУ. Економічні науки. 2005. № 4 (34). С. 3 - 21.

18.Голов С. Ф., Костученко В. М. Бухгалтерський облік за міжнародними стандартами : приклади та коментарі : практичний посібник. К. : Лібра, 2001. 840 с.

19.Сфіменко В., Тягнирядно Л. Розвиток бухгалтерського обліку в Україні: проблеми теорії та практики // Бухгалтерський облік і аудит. 2012. № 12. С.3-7.

20.Пархоменко В. М. Свроконвергенція бухгалтерського обліку // Науково-практичний журнал «Бухгалтерський облік і аудит». 2014. № 8. С. 3 - 4.

21.Свірко С. Реформування бухгалтерського обліку бюджетних установ в Україні // Проблеми формування ринкової економіки: Зб. наук. праць. Спец. випуск. Проблеми трансформації бухгалтерського обліку, аналізу і аудиту в системі міжнародних стандартів. К.: КНЕУ, 2001. C. 33 - 40.

22.Кужельний М. Процеси реформування обліку i контролю в Україні // Проблеми формування ринкової економіки : зб. наук. пр. Київ : КНЕУ, 2001. Спец. вип.: Проблеми трансформації бухгалтерського обліку, аналізу і аудиту в системі міжнародних стандартів. C. 226-228.

23.Кузьмінський Ю. Що таке система бухгалтерського обліку? // Бухгалтерський облік i аудит. 2006. № 6. С. 8-11.

24. Охріменко О. О., Іванова Т. В. Соціальна відповідальність : навч. посіб. НТУУ «КПІ». $2015.180 \mathrm{c}$.

25.Нефінансова звітність за стандартом GRI у світі та Україні : офіційний сайт компанії «Baker Tilly» URL: http://www.bakertilly.ua/.

26. Господарський кодекс України : закон України від 16.01.2003 p. № 436-IV (зі змінами та доповненнями станом на 06.11 .2017 p.) URL: http://zakon4.rada.gov.ua/laws/show/436-15/page. 